\title{
Exploring the economic case for early investment in climate change mitigation in middle-income countries: a case study of Johor Bahru, Malaysia
}

\section{Sarah Colenbrander, Andy Gouldson, Andrew Heshedahl Sudmant, Effie Papargyropoulou, Loon Wai Chau \& Chin Siong Ho}

To cite this article: Sarah Colenbrander, Andy Gouldson, Andrew Heshedahl Sudmant, Effie Papargyropoulou, Loon Wai Chau \& Chin Siong Ho (2016) Exploring the economic case for early investment in climate change mitigation in middle-income countries: a case study of Johor Bahru, Malaysia, Climate and Development, 8:4, 351-364, DOI: 10.1080/17565529.2015.1040367

To link to this article: http://dx.doi.org/10.1080/17565529.2015.1040367

$$
\begin{aligned}
& \text { (c) } 2015 \text { The Author(s). Published by Taylor \& } \text { Francis. } \\
& \text { Frablished online: } 02 \text { Jun } 2015 .
\end{aligned}
$$

Submit your article to this journal ๔

View related articles

Citing articles: 4 View citing articles $ऍ$ 


\title{
RESEARCH ARTICLE
}

\section{Exploring the economic case for early investment in climate change mitigation in middle-income countries: a case study of Johor Bahru, Malaysia}

\author{
Sarah Colenbrander ${ }^{\mathrm{a}}$, Andy Gouldson ${ }^{\mathrm{a}}$, Andrew Heshedahl Sudmant ${ }^{\mathrm{a}}$, Effie Papargyropoulou ${ }^{\mathrm{b}}$, Loon Wai Chau ${ }^{\mathrm{c}}$ and Chin \\ Siong $\mathrm{Ho}^{\mathrm{c}}$ \\ ${ }^{a}$ School of Earth and Environment, University of Leeds, Leeds LS2 9JT, UK; ${ }^{b}$ Malaysia-Japan International Institute of Technology, \\ Universiti Teknologi Malaysia, 54100 Kuala Lumpur, Malaysia; ${ }^{c}$ Department of Urban and Regional Planning, Universiti Teknologi \\ Malaysia, 81310 Johor Bahru, Malaysia
}

(Received 30 August 2014; accepted 22 January 2015)

\begin{abstract}
The assumption that climate mitigation can only be afforded at a particular level of income is implicit in global climate negotiations. This suggests that middle-income countries may reach a tipping point in their development process where low-carbon investment becomes more viable. In order to avoid dangerous levels of climate change, this tipping point needs to be brought forward in time: upper-middle-income countries are already responsible for $37.8 \%$ of global $\mathrm{CO}_{2}$ emissions. We explore the scope for large-scale investment in climate mitigation in Johor Bahru, a fast-growing industrial city in Malaysia. We find that the city could reduce per capita emissions by $10.0 \%$ by 2025 , relative to 2014 levels, through cost-effective investments. If the returns could be recovered and reinvested in low-carbon measures, Johor Bahru could reduce per capita emissions by $35.2 \%$ by 2025 , relative to 2014 levels. This result suggests that the tipping point may be a function of political will and institutional capacity as well as income. This has substantial implications for global climate policy discussions, particularly the opportunities and responsibilities of middle-income countries. If comparable savings can be delivered across cities in middle-income countries, this would equate to a reduction in global emissions of $6.3 \%$ with the exploitation of cost-effective options and $11.3 \%$ with the exploitation of cost-neutral options. Investing in economically attractive low-carbon measures could also provide cities in middle-income countries with an opportunity to build the political momentum and institutional capacities necessary for deeper decarbonization.
\end{abstract}

Keywords: energy; climate policy; cities; carbon Kuznets curve; low-carbon investment

\section{Introduction}

\subsection{Trade-offs between economic growth and climate change mitigation}

The assumption that there are trade-offs between economic development and climate change mitigation is implicit in international climate change negotiations. Greenhouse gas emission reductions are perceived to be costly, so the allocation of future emissions and responsibility for emission reductions are fiercely disputed (Beltran, den Elzen, Hof, van Vuuren, \& van Vliet, 2011; Lipford \& Yandle, 2010). Consequently, only countries with a high-income per capita are expected to reduce their emissions, while developing countries with a low average income per capita are expected to prioritize human development over environmental action. This is explicit in the Kyoto Protocol in the form of legally binding emission reduction obligations for developed countries and the promise of financial resources to meet additional costs incurred for developing countries (UNFCCC, 1992).
The idea that investment in climate change mitigation can only be afforded at a particular level of income implies that middle-income countries may reach a tipping point in their development process where such investment becomes more viable. In order to avoid exceeding a global temperature rise of more than $2^{\circ} \mathrm{C}$, it is important that this tipping point is (a) better understood and (b) brought forward in time. Upper-middle-income countries such as Brazil, China, Malaysia, Mexico and Turkey are already responsible for $37.8 \%$ of global $\mathrm{CO}_{2}$ emissions (World Bank, 2014a), and emerging economies will be responsible for more than $90 \%$ of the projected growth in energy demand over the next two decades (IEA, 2013). With this anticipated expansion of energy use and without a transition to low-carbon energy sources, the world is on a trajectory consistent with an average temperature increase of $3.6^{\circ} \mathrm{C}$ by 2100 (IEA, 2013). Although they currently have no binding targets under the Kyoto Protocol, middle-income countries must therefore identify and

\footnotetext{
*Corresponding author. Email: s.colenbrander@leeds.ac.uk
} 


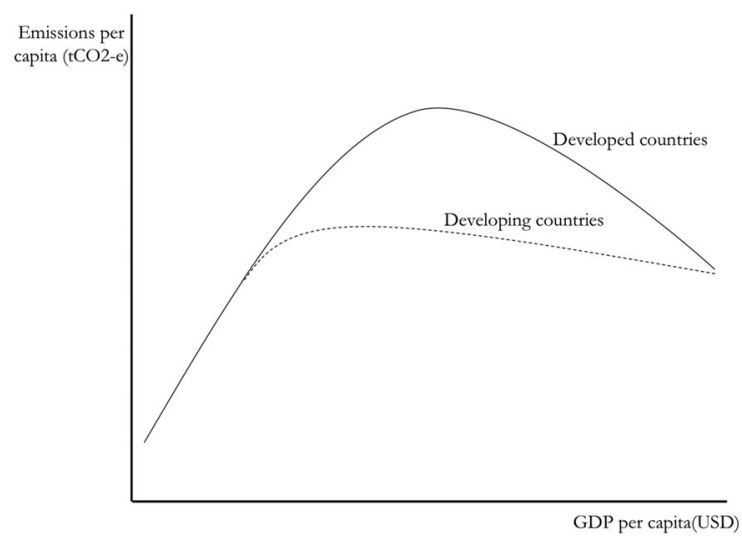

Figure 1. A comparison of the high-carbon development path historically pursued by developed countries and the low-carbon development path that emerging economies need to pursue in order to mitigate climate change.

transition to lower carbon development paths to avoid dangerous levels of climate change.

Decision-makers can avoid perceived trade-offs with human development goals if climate policies do not incur economic costs - and can actively support the realization of development goals if climate policies generate economic benefits. We therefore need to identify low-carbon options that are at least cost-neutral and at best cost-effective. Exploitation of these options would allow developing countries to reduce carbon emissions at a lower level and at an earlier stage of development than we have historically observed for developed countries, as represented in Figure 1.

\subsection{Tunnelling through the carbon Kuznets curve}

The theory that pollution reduction can only be afforded at higher levels of income has been represented by the environmental Kuznets curve (EKC). The EKC was first proposed by Grossman and Krueger (1991) and was then popularized in the World Development Report (Shafik \& Bandyopadhyay, 1992; World Bank, 1992). The EKC proposes an inverted U-shaped relationship between environmental degradation and income per capita. In other words, the early stages of economic growth entail increasing pollution and declining environmental quality until, at some level of income per capita, the trend reverses and economic growth leads to improving environmental quality. These environmental improvements are not inevitable. Shafik and Bandyopadhyay (1992) highlight that environmental gains require costly policies and investments that are typically only undertaken where there are generalized local costs and substantial private or social benefits.

The EKC hypothesis is unlikely to apply to greenhouse gas emissions in light of their long-term effects, minimal immediate impact on quality of life and relatively high abatement cost (Arrow et al., 1995; Dinda, 2004). Smith and Ezzati (2005) particularly questioned the implication that 'countries could grow their way out of environmental problems' (p. 324). The empirical evidence to date is not compelling: efficiency improvements or decarbonization of energy rarely outstrip increasing energy use and economic activity (e.g. Azomahou, Laisney, \& Nguyen Van, 2006; Lamb et al., 2014; Mundaca, Markandya, \& Nørgaard, 2013a), while others find the distinct inverse $\mathrm{U}$-shaped curve only in the presence of specific climate policies or energy scenarios (e.g. Liddle \& Messinis, 2014; López-Menéndez, Pérez, \& Moreno, 2014). These results are supported by broader work on the EKC which has found that decoupling of economic growth and pollutants depends on effective environmental regulation, technological diffusion and avenues for public participation in policy-making, which may or may not correlate with higher incomes (Carson, 2010; Gani, 2012; Steer, 2013).

While the empirical evidence for an EKC may be lacking, the theory of an inverted U-shaped carbon Kuznets curve (CKC) has relevance with respect to the concept of a tipping point. Previous theoretical work has proposed that newly industrialized countries can avoid peak emissions by 'tunnelling through' the EKC (Munasinghe, 1999) through establishing environmental regulation at an earlier stage of development and leapfrogging to cleaner technologies. To date, there is little evidence either of the economic potential to 'green' economic growth or of decoupling between GDP and carbon-intensive energy use (Scrieciu, Rezai, \& Mechler, 2013). We aim to respond to this gap in the literature by establishing whether a city in an upper-middle-income country can achieve a tipping point in its carbon emissions - effectively tunnel through the CKC - at no net cost.

This research seeks to test the assumption that reducing greenhouse gases entails economic costs that can only be afforded with further development and increased income. Evidence of a strong economic case for low-carbon measures would suggest that there are not always tradeoffs between development and mitigation. This may help to foster a new discourse focusing on the economic benefits of climate action, which will hopefully help mobilize decision-makers in emerging economies to make the policies and investments necessary to reduce carbon emissions.

\subsection{Achieving low-carbon urban development}

Cities are currently responsible for $67-76 \%$ of energy use and $71-76 \%$ of energy-related $\mathrm{CO}_{2}$ emissions (IPCC, 2014). Their share of global energy demand and carbon emissions is likely to increase due to, among other factors, rapid urbanization in developing countries: cities 
in the developing world are projected to increase by 2.7 billion people by 2050 (IPCC, 2014; UNDESA, 2013; WHO, 2014). While cities' share of global emissions is high and rising fast, their socio-economic dynamism and concentration of infrastructure also mean that cities are uniquely positioned to tackle climate change.

Municipal authorities can reduce the carbon intensity of cities through land-use regulation, the issue of planning permits and enforcement of energy regulation, which in turn will influence urban spatial structure, transportation systems and energy technologies (Phdungsilp, 2009; Zusman, Srinivasa, \& Dhakal, 2012). This is particularly true in fast-growing emerging economies such as Malaysia, where massive investment is necessary to redress historical infrastructure deficits and address rapid population and economic growth. While established cities in the developed world are struggling to break out of highcarbon economic models, developing world cities like Johor Bahru can avoid 'lock-in' by integrating climate considerations at an early stage of urban development. Their institutional capacities and responsibilities mean that cities have the ability to act on climate change; their relatively large and fast-growing carbon footprints mean that their actions have significant potential to reduce emissions.

This paper evaluates the existence and extent of the economic case for low-carbon investment in the city of Johor Bahru, Malaysia, to determine whether the city could reduce emissions per capita without affecting growth of GDP per capita - in other words, whether Johor Bahru could tunnel through the CKC in a cost-effective or cost-neutral way. Malaysia is pursuing an exceptionally carbon-intensive development path, with most of its projected growth in population, economic activity and greenhouse gas emissions projected to come from second-tier cities such as Johor Bahru. Evidence of an economic case for climate action should prompt decisionmakers at local and national levels to re-evaluate the relationship between economic growth and climate change mitigation, thereby - hopefully - helping to build the political will for climate action at an earlier stage of development.

The remainder of this paper is structured as follows. Section 2 presents the case study and the methods employed for data collection and analysis. Section 3 provides the empirical results. Section 4 discusses the implications for climate change negotiations and offers some policy recommendations to help realize these opportunities. The conclusions are presented in Section 5. This work builds on the Low Carbon Society Blueprint for Iskandar Malaysia 2025 (Ho et al., 2013; UTM, IRDA, Kyoto University, Okayama University, \& National Institute for Environmental Studies, 2013) and the Climate Smart Cities programme (Gouldson, Colenbrander, Sudmant, \& Papargyropoulou, 2014).

\section{Methods}

This paper explores the scope for large-scale investment in climate mitigation at the city scale, using the case study of Johor Bahru, Malaysia. It presents a bottom-up assessment of the investment needs, returns and carbon savings of a wide range of low-carbon measures. The impacts of these measures are compared against 'business as usual' modes of development for the city's energy use, energy bills and carbon emissions in the next 10 years. The findings are drawn together to determine the economic case for lowcarbon investment in the city, and the impact on emissions on a per capita and city-scale basis.

The quantitative research presented here focuses on the direct economic costs and benefits of different low-carbon measures in a city, and does not formally consider the social and environmental impacts of each option. This is not meant to downplay the importance of assessing the social case for low-carbon investment. However, the aim here is to test whether carbon emissions can be reduced in a cost-effective or cost-neutral way in order to test the assumption that climate policies entail economic costs.

\subsection{Case study: Johor Bahru, Malaysia}

Energy consumption per capita is relatively high in Malaysia at 2.63 toe per capita, compared to other upper-middleincome countries such as Brazil at 1.37, Turkey at 1.54 or China at 1.7 (World Bank, 2014b). High energy consumption combined with relatively carbon-intensive energy means that Malaysian emissions per capita are 64\% higher than the world average (UNDESA, 2014). Nonetheless, per capita energy consumption in Malaysia is only $61 \%$ of the average for Organisation for Economic Cooperation and Development (OECD) countries (World Bank, 2014b), and Malaysians produce only $76 \%$ of the OECD's average per capita emissions (UNDESA, 2014). There is therefore significant potential for the country to transition to a lower carbon development path than OECD nations.

In a Malaysian context, meaningful emission reductions will depend on action in urban areas. 73\% (21.1 million) of the 29.2 million people of Malaysia live in cities (World Bank, 2014c) and over 90\% of national economic activity is conducted in cities (Muller, 2013). Energy consumption and greenhouse gas emissions are therefore likely to be concentrated in cities for the foreseeable future. Although Kuala Lumpur dominates the Malaysian economic landscape - Klang Valley is home to 7.2 million people and produces $38 \%$ of national GDP (SPAD, 2013) $-48 \%$ of the Malaysian population live in second-tier cities, which generate $52 \%$ of national GDP. These cities therefore have a critical role to play if the country is to avoid locking into a high-carbon development path. 
This study focuses on the city of Johor Bahru as an example of fast-growing, medium-sized Malaysian city. It was chosen as a case study in response to interest in the proposed method and outputs from the Iskandar Regional Development Authority, the government body responsible for development planning and policies in the special economic corridor, Iskandar Malaysia. Johor Bahru is located at the southern tip of Peninsular Malaysia on the Straits of Singapore and has an accordingly hot, humid climate with a mean daily maximum temperature between $30^{\circ} \mathrm{C}$ and $33^{\circ} \mathrm{C}$ all year round and an average of 116 rainy days per year (WMO, 2014). Johor Bahru is the third largest city in Malaysia and serves as an important industrial, logistics and commercial centre. The major industries in the city are plastics manufacturing, electrical and electronic equipment, petrochemical refining and food processing. The main services are wholesale and retail trade, tourism and hospitality, professional and business, transport, medical, educational and financial services (IRDA, 2007). The population in the three key administrative areas (Johor Bahru City Council, Johor Bahru Tengah Municipal Council and Pasir Gudang Municipal Council) is an estimated 1.8 million in 2014 and is expected to reach nearly 2.8 million by 2025 (AECOM, 2009). This expansion is intended to exploit Johor Bahru's strategic location near Singapore, the South China Sea and the Straits of Malacca. Johor Bahru's current GDP per capita (Purchasing Power Parity) is USD 14,790 (IRDA, 2013).

If Johor Bahru achieves its target annual growth rate of $7-8 \%$ (IRDA, 2013), more than half of the urban economy that will exist in 2025 has not been built yet. While imposing substantial challenges, the scale of planned infrastructure investment offers an opportunity to shift the city on to a lower carbon development path - if the various levels of government are willing to make the necessary climate policies and investments.

\subsection{Baseline analysis}

We developed city-scale emission inventories for Johor Bahru for the years 2000-2013 using the methodology outlined in the Greenhouse Gas Protocol for Communities (GPC) v0.9 (C40 Cities Climate Leadership Group and ICLEI Local Governments for Sustainability, 2012). The study therefore considers Scope 1 and 2 emissions, although industrial process emissions had to be excluded because data were not available.

Data on population and GDP per capita for 2005 and 2025 were obtained from the Low Carbon Society Blueprint for Iskandar Malaysia 2025 (UTM et al., 2013) and the Iskandar Regional Development Authority (IRDA, 2013). Data on residential and industrial energy use in Iskandar Malaysia between 2005 and 2025 were obtained from the Low Carbon Society Blueprint (UTM et al., 2013). This was scaled to Johor Bahru using population data from AECOM (2009) and economic data from IRDA (2007) and Khazanah Nasional (2006). Where data were available for 2005 and 2025, a linear relationship was assumed. Data on commercial floor space for 20032013 were obtained from the National Property Information Centre Property Stock Reports (NAPIC, 2014). These figures were multiplied by the average building energy intensity (Saidur, 2009; UNDP \& Malaysian Public Works Department, 2009). Data on the number of vehicles in Johor Bahru between 2005 and 2012 were obtained from the Road Transport Department Malaysia (2014), and data on the fuel efficiency of vehicles from Chen et al. (2003), Silitonga, Atabani, and Mahlia (2012) and Mahlia, Tohno, and Tezuka (2012). The ratio of petrol to diesel cars was assumed to be 3:1. Calculations of waste generation and emissions from the waste collection fleet were based on data from the Integrated Solid Waste Management Blueprint for Iskandar Malaysia (AECOM, 2009) and WRAP (2010). Waste composition, average waste collection rates and recycling rates were based on data provided by the Department of Solid Waste Management (2014).

In order to calculate energy expenditure, nominal energy prices for 2000-2012 were obtained from the Energy Commission (2006-2011) and Ministry of Energy, Green Technology and Water (KeTTHA, 2012). All energy prices were based on those paid by the consumer, and consequently, excluded the additional costs incurred by the government in the form of subsidies. Nominal prices were converted into real prices at 2013 levels using the Consumer Price Index from Malaysian Department of Statistics (2014). An exchange rate of RM1.0 = USD 0.302576 was used, as the average midpoint of bid and ask prices for 2013 (OANDA, 2014).

'Business as usual' baselines for each sector, and for the city as a whole, were developed for the period between 2015 and 2025. Levels and composition of energy use in the commercial, domestic, industrial, transport and waste sectors were forecast to 2025 based on a continuation of historical trends between 2000 and 2014. This method captures business as usual trends in, for example, population growth, economic growth, improvements in energy efficiency and changing consumer behaviour. Projections assume that business as usual trends can continue to 2025 and therefore do not account for, for example, the likely impacts of increasing congestion on growing vehicle ownership.

Trends in greenhouse gas emissions and energy expenditure between 2015 and 2025 are calculated based on the projected changes in the levels and composition of energy use. A 3\% annual increase in real energy prices is assumed between 2014 and 2025, which is conservative compared with historical increases between 2000 and 2013. Projected changes in the carbon intensity of electricity are based on planned investments in new generation capacity for the 
Peninsular Malaysia grid (Energy Commission, 2006, 2007, 2008, 2009, 2010, 2011). The resulting baselines predict energy consumption, energy bills and carbon footprints through to 2025 under business as usual conditions.

All future activities are compared against these baselines. In practice, Johor Bahru might not be able to sustain its current development trajectory due to, for example, congestion in the transport system. However, the purpose of these baselines is to provide business as usual scenarios against which to measure the potential impacts of the low-carbon measures.

\subsection{Identification and assessment of measures}

Long lists of the energy efficiency, renewable energy and low-carbon measures that could potentially be deployed in each sector of the city are revised through stakeholder consultations to add locally specific measures and remove options that are not applicable in the Malaysian context. The resulting short list is not necessarily exhaustive some measures may have been overlooked, while others may not have been included in the analysis due to the absence of data on their performance. Given the focus of the study on economic valuation of low-carbon measures, this analysis does not consider the impact of significant changes in land-use planning or the spatial distribution of activities within the city. Such modifications to urban form and function are outside the scope of this study.

Again drawing on extensive literature reviews and stakeholder consultations, the performance of each measure on the shortlist is assessed. This involved a cost-benefit analysis of each measure based on the direct, private economic costs and returns from deploying that measure. The costs incorporated the capital, running and maintenance costs of each measure, focusing on the marginal or extra costs of adopting a more energy-efficient or lower carbon alternative. The benefits incorporated the economic savings from reduced energy expenditure over the lifetime of the measure, taking into account installation and performance gaps. The data sources and assumptions are detailed in Appendix A.

As each measure could be in place for many years, the models incorporate the changing carbon intensities of energy use, an average annual rise of $3 \%$ in real prices (including energy prices) and a standard real discount or interest rate of 5\%. For reference, the Central Bank of Malaysia's interest rate was $3.25 \%$ as of July 2014 (BNM, 2014).

\subsection{Assessment of the scope for deployment}

The potential scope for deploying each of the measures in Johor Bahru in the period to 2025 is calculated at a subsector level, taking into account, for example, the scope for change in households with different levels of income.
Realistic rates of deployment are developed based on readily achievable levels of uptake. These assessments take into account the lifespans and replacement rates of existing measures that could be replaced with more energy-efficient or lower carbon alternatives, and also rates of change and growth in the relevant sectors of the city. These are subject to participatory review in the stakeholder workshops to ensure that they are as realistic as possible. The rate of deployment for each measure is detailed in Appendix A and the experts participating in the workshops are detailed in Appendix B.

\subsection{Aggregation of findings}

The results from the assessment of the performance of each measure, and the scope for deploying each measure, are aggregated to determine the potential impact across the different sectors and for the whole city. This underpins calculations of overall investment needs and paybacks, as well as impacts on energy supply and demand in the different sectors in the city. The results are then divided by projected population numbers to determine per capita emissions under the different investment scenarios.

Many low-carbon measures interact with each other, so their performance depends on whether/to what extent another option is also adopted (Bajželj, Allwood, \& Cullen, 2013). For example, the carbon savings from adopting green building standards depend on whether there are also energy efficiency standards for air conditioners. For the purposes of Table 2, the impact of each measure is calculated if it were adopted independently with business as usual conditions in energy supply. When determining the potential savings across the sector or city, the effect of each measure on the potential energy savings of other measures is included to develop realistic assessment of their combined impacts.

In many cases, a single measure has been considered under varying policy conditions: for example, solar photovoltaic (PV) panels with and without feed-in tariffs or waste infrastructure with high and low gate fees. When compiling the sector and city-wide summaries, the cost-effective options that require the least enabling policies have been included unless these policies are already established at scale. Therefore, the total investment needs, energy savings and payback periods reflect those of solar PV panels without feed-in tariffs and waste infrastructure with low gate fees.

\section{Results}

\subsection{Business as usual trends in urban development}

With the continuation of business as usual trends, total energy consumption, energy expenditure and greenhouse gas emissions in Johor Bahru will increase significantly 
over the next decade. Total energy consumption is forecast to rise by $79.4 \%$ from $59.9 \mathrm{TWh}$ in 2014 to a forecast level of $107.4 \mathrm{TWh}$ in 2025 . When combined with increasing real energy prices, this leads total expenditure on energy to increase by $139.9 \%$ from MYR 13.5 billion (USD 4.10 billion) in 2014 to a forecast level of MYR 32.5 billion (USD 9.83 billion) in 2025 (Figure 2). There is some decoupling of economic output and carbon emissions because of energy efficiency improvements in the wider economy. However, economic and population growth outpace these efficiency gains so that carbon emissions attributed to the city are forecast to rise by $83.8 \%$ from $21.0 \mathrm{MtCO}_{2}$-e in 2014 to a forecast level of $38.6 \mathrm{MtCO}_{2}$ $\mathrm{e}$ in 2025. The breakdown of emissions according to sector is shown in Figure 3.

\subsection{The economic case for low-carbon urban development}

The city of Johor Bahru could reduce its carbon emissions by $24.2 \%$ by 2025 , relative to business as usual levels, through cost-effective investments, that is, investments that would more than pay for themselves on commercial terms over their lifetime. This would require an investment of MYR 3.33 billion (USD 1.01 billion), generating annual savings of MYR 2.56 billion (USD 0.77 billion) and paying back the investment in 1.3 years.

If the returns of these investments could be recovered and reinvested in low-carbon measures, Johor Bahru could reduce emissions attributed to the city by $45.4 \%$ in 2025. This would equate to an absolute emission reduction of $0.8 \%$ relative to 2014 levels. Implementing these costneutral measures would require an investment of MYR 18.49 billion (USD 5.59 billion), generating annual cost savings of MYR 2.74 billion (USD 0.83 billion) and paying back the investment in 6.8 years.

The impact of these investments on carbon emissions at the city scale between 2014 and 2025 is shown in Figure 4. The low-carbon measures would continue to generate annual savings throughout their lifetime.

On an individual basis, the deployment of the costeffective low-carbon options would reduce per capita emissions by $10.0 \%$ in real terms, from $11.7 \mathrm{tCO} 2$-e per capita in 2014 to 10.5 tCO2-e per capita in 2025 . The deployment of the cost-neutral options would reduce emissions per capita by a further $25.2 \%$ in real terms, to $7.8 \mathrm{tCO} 2$-e per capita in 2025. The carbon savings per capita are proportionately larger than the carbon savings at the city scale because of rapid population growth in Johor Bahru.

The impact of cost-effective and cost-neutral lowcarbon investments on per capita emissions in Johor Bahru is shown in Figure 5. This figure shows that it is theoretically possible to bring the tipping point forward and start the transition to a lower carbon development path at no net cost for a city in an upper-middle-income country.

While the potential carbon savings are substantial on an individual and city scale, it is important to emphasize that

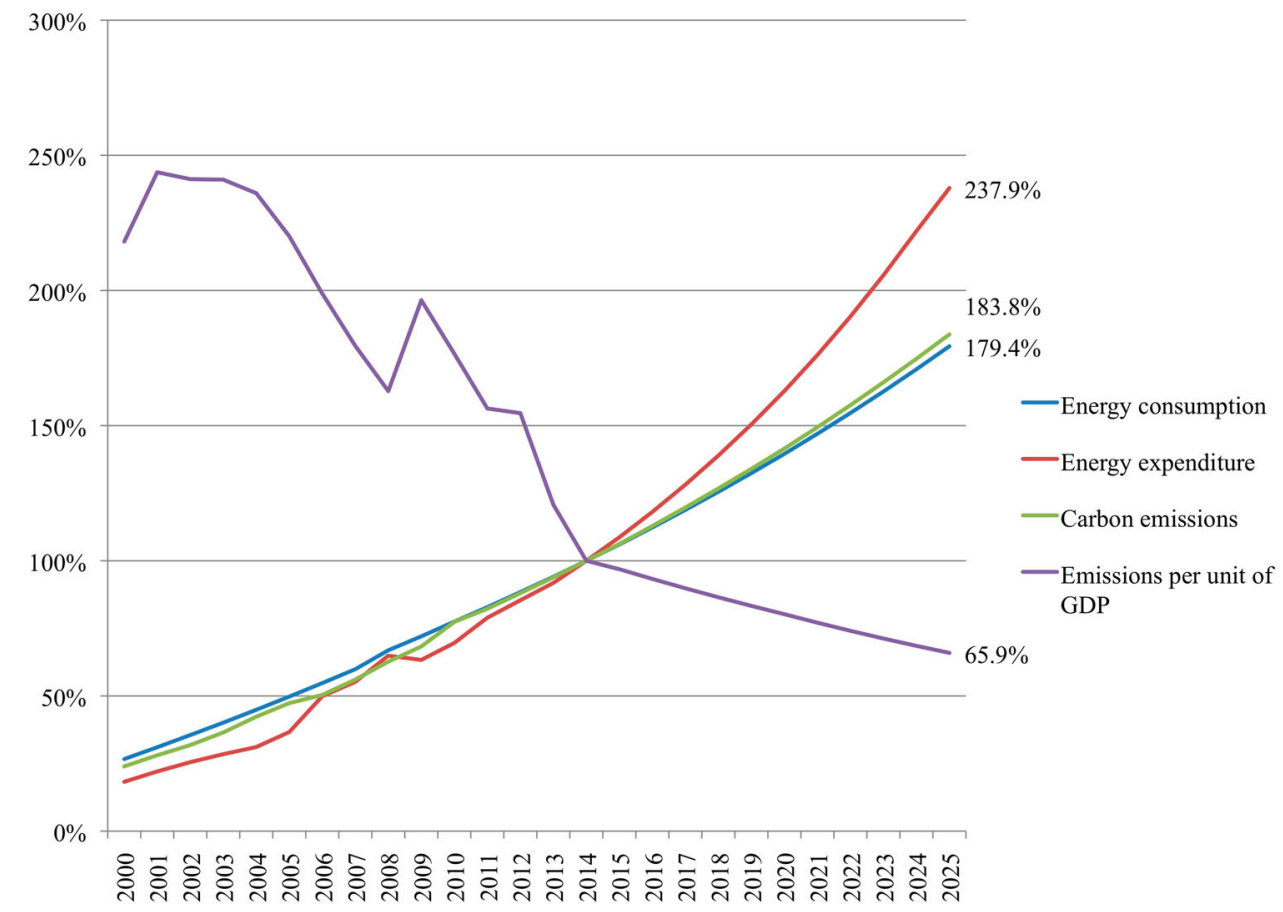

Figure 2. Indexed energy consumption, energy expenditure, carbon emissions and emission intensity of economic activity for the city of Johor Bahru between 2000 and 2025. 


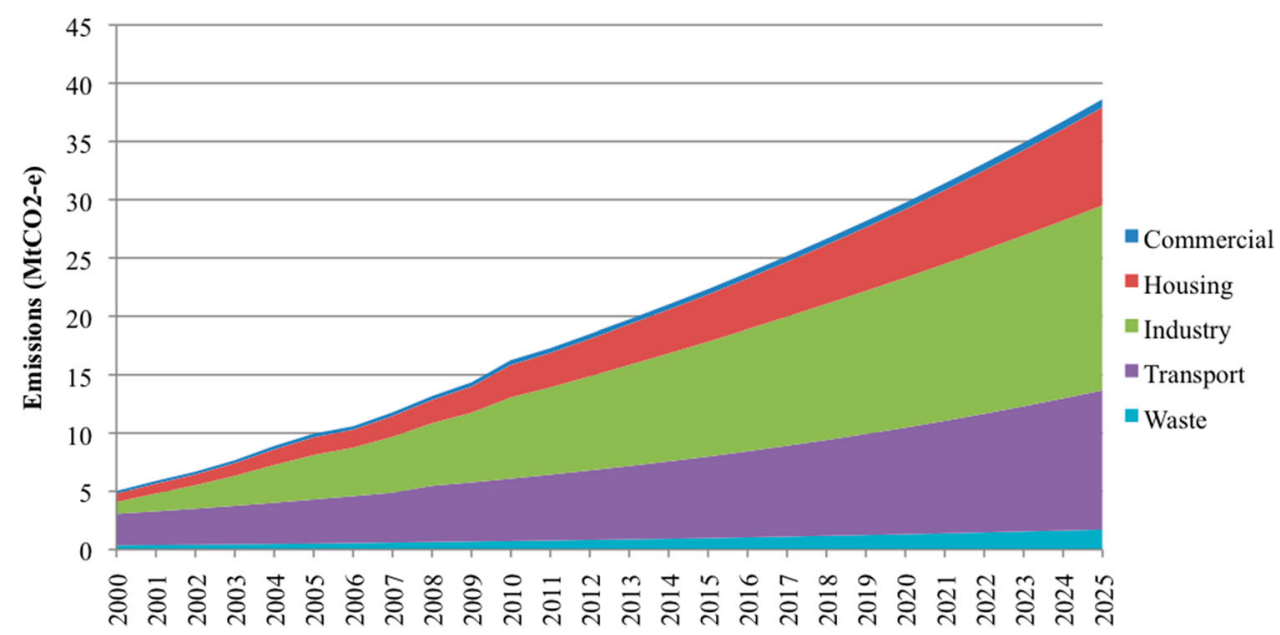

Figure 3. Greenhouse gas emissions $\left(\mathrm{MtCO}_{2}-\mathrm{e}\right)$ by sector for the city of Johor Bahru between 2000 and 2025.

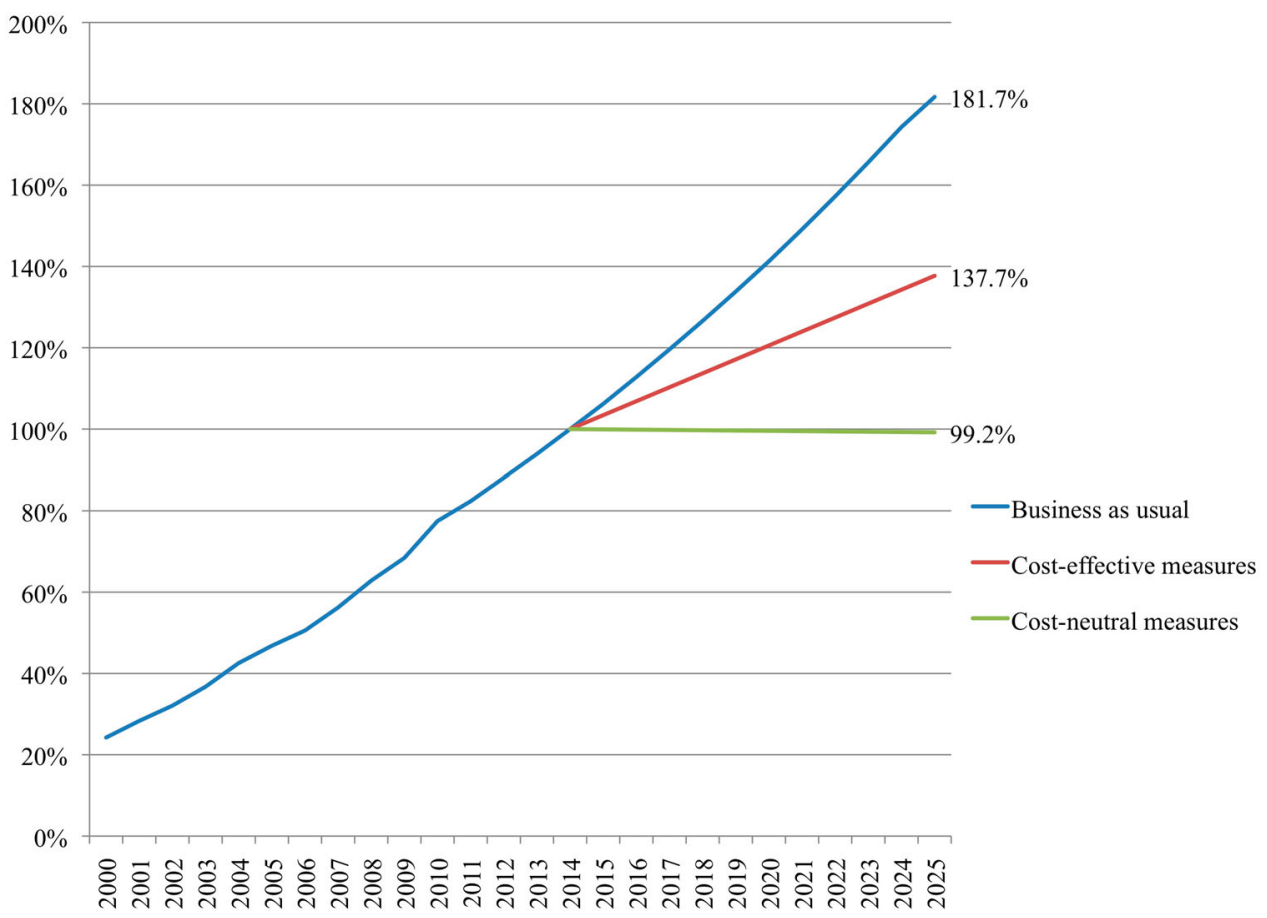

Figure 4. Carbon emissions attributed to Johor Bahru under three different investment scenarios, between 2000 and 2025.

these gains will be temporary without follow-up action. Without further investments to decarbonize energy supply and improve energy efficiency, Johor Bahru risks returning to its current high-carbon development path. This would produce the N-shaped relationship between income and emissions per capita observed by de Bruyn, van den Bergh, and Opschoor (1998), Moomaw and Unrush (1997) and Zanin and Marra (2012). In this case, the city would reach 2025 business as usual emissions in 2030 with exploitation of all cost-effective low-carbon investments and in 2035 with all cost-neutral options. The exploitation of cost-effective and cost-neutral measures therefore buys time to develop political momentum, clean technologies and institutional capacities for climate action. However, they would not allow the city to fully transition on to a lower carbon development path.

\subsection{The cost-effective low-carbon options}

The most significant opportunities to reduce carbon emissions in a cost-effective way in Johor Bahru are in industry and transport (Table 1). These sectors are the largest contributors to climate change in the city, emitting $44.1 \%$ and $31.6 \%$ of the city's greenhouse gases respectively. Fuel 


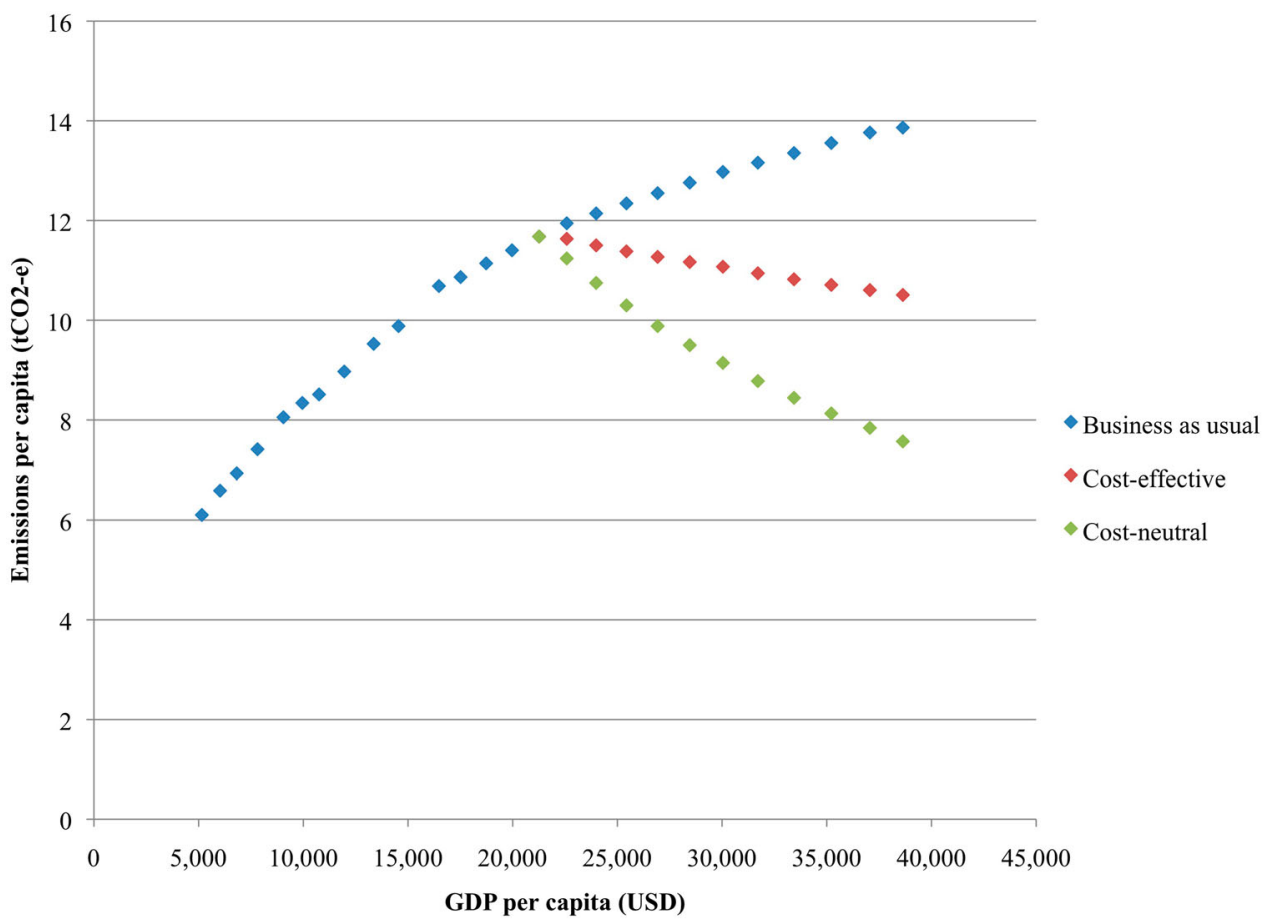

Figure 5. Per capita carbon emissions in Johor Bahru, Malaysia, under three different investment scenarios. Note the resemblance to the CKC.

Table 1. Potential carbon and economic savings available in Johor Bahru in 2025, according to sector.

\begin{tabular}{lcr}
\hline Sector & $\begin{array}{c}\text { Carbon savings } \\
\text { (ktCO2-e) }\end{array}$ & $\begin{array}{c}\text { Economic } \\
\text { savings (USD) }\end{array}$ \\
\hline Commercial & 598 & 57,289 \\
Domestic & 12,004 & 916,720 \\
Industrial & 25,184 & $4,715,647$ \\
Transport & 26,080 & $7,191,129$ \\
Waste & 19,507 & 516,706 \\
\hline
\end{tabular}

switching proves to be an important low-carbon option in both sectors, with significant scope to switch from diesel to natural gas in industry and to increase the share of biofuels in transport. However, while the emission reduction potential in the transport sector is dominated by a single measure (hybrid private cars), the carbon savings in the industry sector would be generated from a wide array of energy efficiency measures, particularly in the rubber and petrochemical industries.

Green building standards in the commercial sector proved to be the most cost-effective low-carbon measure available to the city: this option had to be excluded from Figure 6 because the high savings per unit of emissions distorted the $y$-axis. However, energy-efficient air conditioners prove to be the most carbon-effective option, followed by various lighting efficiency measures. Energy-efficient air conditioners and green building standards in the domestic sector offered significant carbon savings, as did raising thermostat temperatures and deployment of solar PV panels.

The waste sector yields disproportionately large potential for emission reductions relative to its contribution to the city's emissions (4.5\%). This is because energy-from-waste (combined heat and power) and landfill gas utilization options not only reduce methane emissions from landfill but also generate electricity that could displace coal as a source of energy.

The most cost- and carbon-effective measures are identified in Table 2. In this table, cost-effective measures have a negative value: these options save money for every unit of carbon emissions they avoid. Cost-neutral measures have a positive economic value because these options incur a cost to avoid carbon emissions. Those measures with positive economic savings in this table could be paid for through reinvesting the returns from the cost-effective measures. The impact of interactions between these measures has been accounted for in the aggregated investment needs and carbon savings at the sector and city scale.

\section{Discussion}

\subsection{Decoupling economic activity and carbon emissions in Johor Bahru}

Economic growth is outstripping increases in emissions, so the carbon intensity of economic activity in Johor Bahru is projected to fall by $34.1 \%$ over the next decade. Relative 


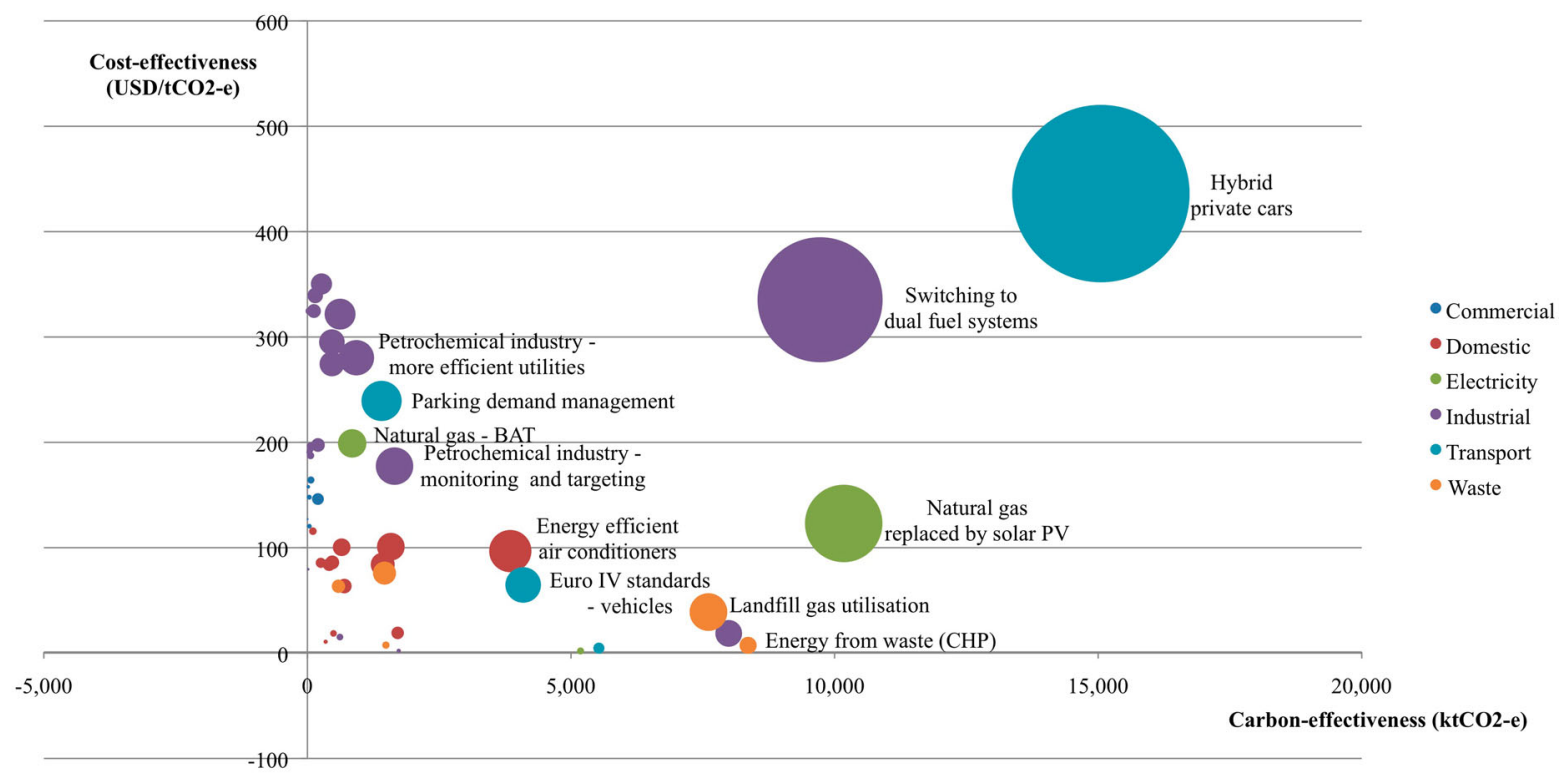

Figure 6. The distribution of cost-effective opportunities according to cost- and carbon effectiveness. The size of the 'bubble' reflects the total economic savings from that measure if deployed independently.

Table 2. League table with the most cost- and carbon-effective measure from each sector. ${ }^{\text {a }}$

\begin{tabular}{|c|c|c|c|c|}
\hline Sector & Measure & MYR/tCO2-e & $\mathrm{USD} / \mathrm{tCO} 2-\mathrm{e}$ & ktCO2-e \\
\hline Commercial & Green Buildings Standard 2 (100\% of new buildings) & $-171,678.44$ & $-51,945.78$ & 173 \\
\hline Industrial & Rubber industry - heat recovery & $-13,136.28$ & -3974.72 & 14.2 \\
\hline Transport & Hybrid private cars with current tax incentive & -1441.31 & -436.11 & 15,051 \\
\hline Industrial & Fertilizer industry - steam reforming (moderate improvements) & -1162.95 & -351.88 & 93.4 \\
\hline Domestic & Raising thermostat $1{ }^{\circ} \mathrm{C}$ & -333.65 & -100.95 & 1582 \\
\hline Transport & Euro IV vehicle standards - cars with sales tax relief & -969.46 & -293.34 & 9169 \\
\hline Commercial & Banning incandescent light bulbs & -542.82 & -164.24 & 65.76 \\
\hline Domestic & $4 \mathrm{kWp}$ solar PV panel with FiT (10 MW by 2025$)$ & -505.19 & -152.86 & 1712 \\
\hline Commercial & Air conditioner - EE standard 2 & -483.11 & -146.18 & 199 \\
\hline Domestic & Solar water heating with FiT ( $15 \%$ of households by 2025$)$ & -435.20 & -131.68 & 438 \\
\hline Domestic & Air conditioner - EE Standard 2 & -319.87 & -96.78 & 3849 \\
\hline Waste & Centralized composting - high gate fee & -250.77 & -75.88 & 1462 \\
\hline Waste & Waste prevention & -209.59 & -63.42 & 589 \\
\hline Waste & Landfill gas utilization & -128.66 & -38.93 & 7607 \\
\hline Waste & Energy from waste (combined heat and power) - high gate fee & -24.11 & -7.30 & 8359 \\
\hline Commercial & Turning off lights & -0.53 & -0.16 & 145 \\
\hline Industrial & Fuel switching - diesel replaced with biodiesel & 48.21 & 14.59 & 43,798 \\
\hline Industrial & $\begin{array}{l}\text { Rubber industry - adoption of variable speed drive in } \\
\text { electric motors ( } 30 \% \text { speed reduction) }\end{array}$ & 183.52 & 55.53 & 11,232 \\
\hline Transport & B100 fuel & 207.86 & 62.89 & 19,874 \\
\hline Transport & BRT $(50 \mathrm{~km})$ & 342.05 & 103.50 & 3154 \\
\hline
\end{tabular}

Note: Where two measures are mutually exclusive, the more carbon-effective option has been included.

${ }^{\mathrm{a}}$ Full details are available upon request.

decoupling of economic output and carbon emissions is therefore apparent in business as usual trends between 2000 and 2025. However, absolute levels of emissions attributed to the city are projected to rise at a rate of $5.8 \%$ per annum between 2014 and 2025. This means that emissions per capita in Johor Bahru are projected to reach $13.9 \mathrm{tCO}_{2}$-e in 2025 , that is, $36.9 \%$ higher than average per capita emissions in OECD countries in 2010 (World Bank, 2014d). Johor Bahru is therefore on a highcarbon development path.

Reaching the tipping point in absolute carbon emissions will require absolute rather than relative decoupling. There is substantial potential to curb growth in emissions per capita through exploitation of economically attractive 
options. If the city were to invest the equivalent of $0.4 \%$ of GDP in cost-effective low-carbon measures annually for 10 years, it would yield reductions in the city's energy bill equal to $1.0 \%$ of GDP per year. These measures would reduce emissions at the city scale by $24.2 \%$ relative to business as usual trends. This would not halt the growth in emissions at the city scale: emissions still increase by $37.7 \%$ relative to 2014 levels in 2025 (Figure 2) because carbon savings are outstripped by rapid population growth. On a per capita basis, however, these investments would reduce emissions by $10.0 \%$. This suggests that absolute decoupling of economic activity and carbon emissions is possible in a cost-effective way in a city in an upper-middle-income country.

If the returns from the cost-effective measures could be recovered without substantial transaction costs and reinvested in low-carbon measures, there is scope to reduce emissions even further. In this cost-neutral scenario, Johor Bahru could reduce its emissions to $45.4 \%$ relative to business as usual levels in 2025. This is equivalent to a reduction of $0.8 \%$ in real terms relative to 2014 levels. In other words, the city as a whole can achieve real emission reductions and decouple economic development from carbon emissions at no net cost (Figure 4). These results are even more compelling at an individual scale. With exploitation of all of the cost-effective and cost-neutral carbon saving potential in Johor Bahru, emissions per capita could be reduced by $35.2 \%$ relative to 2014 levels. To put this in context, the Malaysian government has voluntarily committed to reducing the emission intensity of GDP by up to $40 \%$ based on 2005 levels by 2020 (Ministry of Natural Resources and Environment, 2010). By comparison, our results indicate that - at least within the city of Johor Bahru - the Malaysian government could reduce emissions per capita below 2005 levels by 2025 in absolute terms (Figure 5).

This finding highlights an important opportunity to mitigate climate change without incurring costs to economic development. Currently, 1.5 billion people live in cities in upper-middle-income countries, and emissions per capita are increasing by $3.5 \%$ per year (World Bank, 2014a). If this trend continues, $\mathrm{CO}_{2}$ emissions from upper-middle-income countries will increase by $46.0 \%$ by 2025 . However, if the results of this research hold broadly true, there is scope to reduce emissions from these cities by $24.2 \%$ in a cost-effective way and by $45.4 \%$ in a cost-neutral way relative to business as usual levels. These savings equate to a reduction respectively equivalent to $6.3 \%$ and $11.3 \%$ of global carbon emissions in 2013. Considering that future growth in energy use and emissions is likely to be concentrated in urban areas of emerging economies, this finding has huge implications for our collective capacity to avoid dangerous climate change.

\subsection{The implications for shifting the tipping point}

The assumption that climate change mitigation can only be afforded at a certain level of income is often evident in international climate policy (e.g. the Kyoto Protocol) and theory (e.g. the hypothesized CKC). It suggests that, under business as usual conditions, middle-income countries will reach a tipping point when low-carbon investment becomes affordable. In practice, of course, many high-income countries have not yet reached a tipping point, so we continue to see a linear relationship between economic growth and carbon emissions at high levels of income, rather than the inverted U-shape of the CKC (Azomahou et al., 2006).

Our findings refute the assumption that this tipping point requires middle-income countries to reach developed country levels of income before they invest in low-carbon development by challenging the premise that emission reductions are costly. This paper identifies a wide range of opportunities that are cost-effective in their own right in an upper-middle-income country. Assuming that these can be deployed in a socially and environmentally responsible way, public authorities could reasonably be expected to invest in these measures purely on economic grounds and this would coincidentally deliver real reductions in per capita emissions. If the returns from these investments can be captured and reinvested in additional low-carbon measures, more substantial emission reductions can be realized at no net cost to the city. The example of Johor Bahru suggests that there can be a compelling economic case for shifting the tipping point to an earlier stage of development. If these savings were sustained, the city would reach 'peak emissions' at a significantly lower level than in a business as usual scenario. It is important to highlight that these carbon savings do not result from reducing territorial emissions by, for example, exporting pollution-intensive industries, which Cole and Neumayer (2005) predicted and Knight and Schor (2014) demonstrated to be the major driver of decoupling in high-income countries. Rather, these are potentially real savings in consumption-based emissions achieved by reducing the carbon intensity of energy use and through energy efficiency improvements. These findings demonstrate that climate policies and investments to reduce emissions can actually be economically attractive, including in the developing world.

These results imply that the tipping point is not a function of income, but of political will and institutional capacity. It can be brought forward in time at no net cost if decision-makers are willing and able to make the necessary low-carbon policies and investments. This is an important extension of existing literature, which shows that it is possible to 'tunnel through' the CKC (e.g. see Aubourg, Good, \& Krutilla, 2008; Lipford \& Yandle, 2010), but does not provide an economic case for such ambitious climate action. 


\subsection{Policy recommendations}

The suggestion that the tipping point is policy dependent and can be cost-neutral should change the nature of global climate policy discussions. The existence of a compelling economic case for low-carbon investments may create the political space for decision-makers to pursue emission reductions at an earlier stage of development than has historically been observed (Gupta, 2012). In other words, demonstrating that the local benefits of action can outweigh the local costs may help to build political will for climate action, which in turn will shift developing countries on to lower carbon development paths. We must therefore consider the ways that, and extent to which, different levels of government can exploit and build upon these opportunities.

It is important to emphasize two points here. First, many of the measures considered here have potentially significant co-costs and benefits, and important distributional consequences and environmental impacts. The direct economic case for different low-carbon options should be only one factor in decision-making: the presence of a wider social case for a low-carbon transition is equally important. For example, an expansion of public transport may improve mobility for the poor while tax incentives for hybrid cars may be largely captured by the relatively wealthy. These impacts should be considered when preparing climate and energy policies.

Second, the approach used here may not fully capture some of the market imperfections associated with the implementation of low-carbon measures, such as transaction costs, agency issues or financing hurdles (Kesicki \& Ekins, 2012). The nature and value of transaction costs is typically specific to different low-carbon measures (Mundaca, Mansoz, Neij, \& Timilsina, 2013b). For example, the introduction of green building standards in Malaysia faces the challenge of split incentives, whereby property developers incur the additional costs while the owner or tenant captures the benefits. Similarly, the replacement of compact fluorescent (CFL) lights with lightemitting diode (LED) bulbs in commercial and public buildings will require much more upfront capital, even if the investment pays for itself within a few years. While evidence from the USA and Europe suggests that ex post transaction costs from climate policy instruments are relatively minor (Joas \& Flachsland, 2014), these considerations mean that governments have a role to play in mobilizing private investment. Public policies and resources can be employed to increase returns, reduce costs, de-risk investments and close knowledge or capacity gaps to encourage widespread uptake of low-carbon options (Buchner et al., 2013). There is therefore a need for more research on climate policy design and project implementation in a Malaysian context.
National governments can reduce the payback periods of low-carbon options by, for example, reducing fossil fuel subsidies or offering feed-in tariffs for renewable energy generation. They can also de-risk low-carbon investments by, for example, setting long-term renewable energy quotas or permitting tax-increment financing for energy efficiency retrofits. National governments also have the capacity to induce private investment through regulation: the adoption of green building standards and more stringent vehicle emission standards are promising examples in a Malaysian context.

These policy tools are not always available to local governments, which have limited resources and powers. However, municipal authorities have considerable capacity to promote more efficient forms of urban development by increasing the stringency of planning and approval processes, enforcing energy regulation and establishing public-private partnerships for large infrastructure projects in the transport and waste sectors. Municipal authorities can also promote energy efficiency by establishing green public procurement policies or by acting as the anchor client for building retrofit programmes. There is evidence that this project-based approach may entail fewer transaction costs and yield more significant co-benefits than, say, national emission trading schemes in the context of non-Annex I countries (Knopf et al., 2010; Spaargaren \& Mol, 2013). The presence of a strong economic case for low-carbon investment provides a compelling incentive to make the necessary regulations and investments at both a national and sub-national level, and it is to be hoped that these will in turn help cities to achieve real emission reductions.

The international community also has a role to play in increasing the returns, reducing the risks or costs and providing a body of evidence that low-carbon options can be economically and socially attractive. There is therefore an urgent need for knowledge transfer to developing countries so that they can exploit more carbon-efficient technologies and establish greener policy frameworks, where these can be deployed at no net cost. Multilateral institutions and development agencies should prioritize the development of locally specific, bottom-up evidence on the economics of different low-carbon options. This will allow local and national policy-makers to identify cost-effective lowcarbon opportunities. Thereafter, strong domestic environmental and energy governance is the key to shifting the tipping point and transitioning to a lower carbon development path.

Where there is less political will or institutional capacities are less developed, policy-makers can cherrypick low-carbon options that are both economically attractive and institutionally straightforward - for example, energy-from-waste infrastructure, hybrid private cars, green building standards for the commercial sector and minimum performance standards for air conditioners - as 
a means to build local capacity and demonstrate economic or technical feasibility. This can provide a platform for the more ambitious and politically complex initiatives, such as transit-oriented urban planning, large-scale deployment of decentralized renewable energy technologies or reductions in energy subsidies.

\section{Conclusions}

Although they are responsible for $37.8 \%$ of global $\mathrm{CO}_{2}$ emissions, upper-middle-income countries currently have no binding emission reductions under international law. This is because of a widely held perception that investment in climate change mitigation can only be afforded when a country reaches a particular level of income. This research suggests that cities in upper-middle-income countries can achieve real emission reductions without hindering economic development; indeed, it outlines a substantial package of low-carbon options that are attractive solely on economic terms that would deliver real emission reductions for the city of Johor Bahru.

This result has important implications for climate policy and practice. First, these findings demonstrate that there are significant carbon savings available from economically attractive low-carbon options. It is reasonable to expect upper-middle-income countries to commit to real emission reductions (rather than emission intensity reductions) that can be achieved in a cost-effective or cost-neutral way.

Second, this work highlights that substantial private investment in low-carbon options can be mobilized with enabling policy frameworks. The presence of a compelling economic case for climate action will hopefully help to inspire the necessary political leadership at earlier stages of development.

Third, it is important to emphasize that ongoing lowcarbon investments will be required to maintain the lower carbon intensity of economic growth. These may not always be cost-effective or cost-neutral. Empirical research indicates that countries may achieve some emission reductions which are subsequently lost by a return to carbon-intensive economic growth - resulting in the Nshaped CKC (de Bruyn et al., 1998; Moomaw \& Unrush, 1997; Zanin \& Marra, 2012). With careful design and delivery, exploitation of cost-effective low-carbon options can increase public acceptance of climate action, support social and economic development and build institutional capacities for implementing and financing climate mitigation. The economic case for low-carbon investment therefore provides a means to build political momentum for deeper structural changes that may or may not be economically attractive, but are necessary to achieve the levels of decarbonization necessary to avoid dangerous climate change.

\section{Disclosure statement}

No potential conflict of interest was reported by the authors.

\section{References}

AECOM. (2009). Iskandar Malaysia Integrated Solid Waste Management Blueprint. Retrieved July 24, 2014, from http://www.sisa.my/sisanet/1upload/lokasi/Johor/document/ mesyuarat_pengarah_negeri/Arkib/Iskandar\%20Malayisa\% 20Integrated $\% 20$ Solid $\% 20$ Waste $\% 20$ Management $\% 20$ Blue print_Stage\%203\%20Final\%20Report.pdf

Arrow, K., Bolin, B., Costanza, R., Dasgupta, P., Folke, C., Holling, C. S., ... Pimentel, D. (1995). Economic growth, carrying capacity and the environment. Ecological Economics, $15,91-95$.

Aubourg, R. W., Good, D. H., \& Krutilla, K. (2008). Debt, democratization and development in Latin America: How policy can affect global warming. Journal of Policy Analysis and Management, 27(1), 7-19.

Azomahou, T., Laisney, F., \& Nguyen Van, P. (2006). Economic development and $\mathrm{CO}_{2}$ emissions: A nonparametric panel approach. Journal of Public Economics, 90, 1347-1363.

Bajželj, B., Allwood, J. M., \& Cullen, J. M. (2013). Designing climate change mitigation plans that add up. Environmental Science and Technology, 47(14), 8062-8069.

Beltran, A. M., den Elzen, M. G. J., Hof, A. F., van Vuuren, D. P., \& van Vliet, J. (2011). Exploring the bargaining space within international climate negotiations based on political, economic and environmental considerations. Energy Policy, 39 (11), 7361-7371.

BNM. (2014). Conventional interbank rates. Bank Negara Malaysia. Retrieved July 25, 2014, from http://www.bnm. gov.my/index.php?ch=statistic\&pg=stats_convinterbkrates

de Bruyn, S. M., van den Bergh, J. C. J. M., \& Opschoor, J. B. (1998). Economic growth and emissions: Reconsidering the empirical basis of environmental Kuznets curves. Ecological Economics, 25, 161-175.

Buchner, B., Herve-Mignucci, M., Trabacchi, C., Wilkinson, J., Stadelmann, M., Boyd, R., ... Micale, V. (2013). The global landscape of climate finance 2013. Climate Policy Initiative. Retrieved January 14, 2015, from http:// climatepolicyinitiative.org/wp-content/uploads/2013/10/TheGlobal-Landscape-of-Climate-Finance-2013.pdf

C40 Cities Climate Leadership Group and ICLEI Local Governments for Sustainability. (2012). Greenhouse Gas Protocol for Communities v0.9. Retrieved February 3, 2014, from http://www.ghgprotocol.org/files/ghgp/GPC\% 20v9\%2020120320.pdf

Carson, R. T. (2010). The environmental Kuznets curve: Seeking empirical regularity and theoretical structure. Review of Environmental Economics and Policy, 4(1), 3-23.

Chen, K. S., Wang, W. C., Chen, H. M., Lin, C. F., Hsu, H. C., Kao, J. H., \& Hu, M. T. (2003). Motorcycle emissions and fuel consumption in urban and rural driving conditions. The Science of the Total Environment, 312, 113-122.

Cole, M. A., \& Neumayer, E. (2005). Environmental policy and the environmental Kuznets curve: Can developing countries escape the detrimental consequences of economic growth? In P. Dauvergne (Ed.), Handbook of global environmental politics (pp. 298-318). Cheltenham: Edward Elgar.

Department of Statistics. (2014). Consumer price index. Malaysia: Author. Retrieved April 16, 2014, from http://www.statistics. gov.my/portal/index.php?option=com_content\&view=article\& $\mathrm{id}=583 \&$ Itemid=111\&lang=en 
Department of Solid Waste Management. (2014). Solid waste composition report. Ministry of Urban Wellbeing, Housing and Local Government, Malaysia. Retrieved April 30, 2014, from http://www.kpkt.gov.my/jpspn_en_2013/main. php? Content $=$ articles\&ArticleID $=43 \& \mathrm{IID}=$

Dinda, S. (2004). Environmental Kuznets curve hypothesis: A survey. Ecological Economics, 49, 431-455.

Energy Commission. (2006). Electricity supply industry in Malaysia - performance and statistical information 2006. Malaysia Energy Hub. Retrieved July 24, 2014, from http:// meih.st.gov.my/documents/10620/969e79a4-aa17-46ec-a20 $1-6384 \mathrm{bb} 18 \mathrm{e} 6 \mathrm{dc}$

Energy Commission. (2007). Electricity supply industry in Malaysia - performance and statistical information 2007. Malaysia Energy Hub. Retrieved July 24, 2014, from http:// meih.st.gov.my/documents/10620/b10baadc-ab2c-488b-a4af $-57 \mathrm{e} 1 \mathrm{f} 4 \mathrm{~d} 4 \mathrm{~d} 7 \mathrm{a} 3$

Energy Commission. (2008). Electricity supply industry in Malaysia - performance and statistical information 2008. Malaysia Energy Hub. Retrieved July 24, 2014, from http:/ meih.st.gov.my/documents/10620/c569e1d5-542f-407c-ad 31 -acdd2d4353a6

Energy Commission. (2009). Electricity supply industry in Malaysia - performance and statistical information 2009. Malaysia Energy Hub. Retrieved July 24, 2014, from http:// meih.st.gov.my/documents/10620/5c011fd7-4cae-4a09-891 a-8794c1404d58

Energy Commission. (2010). Electricity supply industry in Malaysia - performance and statistical information 2010. Malaysia Energy Hub. Retrieved July 24, 2014, from http:// meih.st.gov.my/documents/10620/e92bbc28-ff35-4e80-8981a849b2fce14b

Energy Commission. (2011). Electricity supply industry in Malaysia - performance and statistical information 2011. Malaysia Energy Hub. Retrieved July 24, 2014, from http:/ meih.st.gov.my/documents/10620/a2d10c59-1931-4e73-94 ba-630d6be 34575

Gani, A. (2012). The relationship between good governance and carbon dioxide emissions: Evidence from developing economies. Journal of Economic Development, 77(37), 77-93.

Gouldson, A., Colenbrander, S., Sudmant, A., \& Papargyropoulou, E. (2014). The economics of low carbon cities: Johor Bahru and Pasir Gudang, Malaysia. The Centre for Low Carbon Futures. Retrieved August 20, 2014, from http://www. climatesmartcities.org/sites/default/files/Malaysia\%20-\%20Ex ecutive $\% 20$ Summary $\% 20$ (English).pdf

Grossman, G. M., \& Krueger, A. B. (1991). Environmental impacts of a North American free trade agreement (National Bureau of Economic Research Working Paper 3914). Cambridge, MA: NBER.

Gupta, J. (2012). Negotiating challenges and climate change. Climate Policy, 12(5), 630-644.

Ho, C. S., Matsuoka, Y., Chau, L. W., Teh, B. T., Simpson, J. J., \& Gomi, K. (2013, March 4-6). Bridging science and policymaking: Low Carbon Society Blueprint for Iskandar Malaysia. Proceeding of 7th South East Asia Technical University Consortium (SEATUC) 2013 symposium, Institut Teknologi Bandung, Indonesia.

IEA. (2013). World energy outlook 2013. Paris: Author. Retrieved July 28, 2015, from http://www.worldenergyoutlook.org/ publications/weo-2013/

IPCC. (2014). Climate change 2014: Mitigation of climate change. Author. Retrieved May 15, 2014, from http:// mitigation2014.org
IRDA. (2007). Iskandar Malaysia comprehensive development plan. Retrieved April 30, 2014, from http://www.iskandarm alaysia.com.my/comprehensive-development-plan-cdp

IRDA. (2013). What is Iskandar Malaysia: Facts \& figures. Malaysia: Author. Retrieved November 14, 2013, from http://www.iskandarmalaysia.com.my/what-is-iskandar-mala ysia-fact-figures

Joas, F., \& Flachsland, C. (2014). The (ir)relevance of transaction costs in climate policy instrument choice: An analysis of the EU and the US. Climate Policy. doi:10.1080/14693062. 2014.968762

Kesicki, F., \& Ekins, P. (2012). Marginal abatement cost curves: a call for caution. Climate Policy, 12(2), 219-236. doi:10.1080/ 14693062.2011 .582347

KeTTHA. (2012). National energy balance 2011. Ministry of Energy, Green Technology and Water. Retrieved April 9, 2014, from http://meih.st.gov.my/documents/10620/6ee11 9f3-8bcf-4a7b-930e-ae375dbbc544

Khazanah Nasional. (2006). Comprehensive development plan for South Johor economic region. Retrieved April 16, 2014, from $\mathrm{http} / / / \mathrm{www}$.iskandarmalaysia.com.my/pdf/cdp/7._Chapter4_Economic_Development_Strategies.pdf

Knight, K. W., \& Schor, J. B. (2014). Economic growth and climate change: A cross-national analysis of territorial and consumption-based carbon emissions in high-income countries. Sustainability, 6(6), 3722-3731. doi:10.3390/ su6063722

Knopf, B., Edenhofer, O., Flachsland, C., Kok, M. T. J., LotzeCampen, H., Luderer,... van Vuuren, D. P. (2010). Managing the low-carbon transition - from model results to policies. The Energy Journal [The Economics of Low Stabilization], 31(1), 233-245.

Lamb, W. F., Steinberger, J. K., Bows-Larkin, A., Peters, G. P., Roberts, J. T., \& Wood, F. R. (2014). Transitions in pathways of human development and carbon emissions. Environmental Research Letters, 9(1). doi:10.1088/17489326/9/1/014011

Liddle, B., \& Messinis, G. (2014). Revisiting carbon Kuznets curves with endogenous breaks modeling: Evidence of decoupling and saturation (but few invested-us) for individual OECD countries (United States Association for Energy Economics - USAEE Research Paper No. 14-178).

Lipford, J. Y., \& Yandle, B. (2010). Environmental Kuznets curves, carbon emissions and public choice. Environment and Development Economics, 15(4), 417-438.

López-Menéndez, A. J., Pérez, R., \& Moreno, B. (2014). Environmental costs and renewable energy: Re-visiting the environmental Kuznets curve. Journal of Environmental Management, 145(1), 368-373. doi:10.1016/j.jenvman. 2014.07.017

Mahlia, T. M. I., Tohno, S., \& Tezuka, T. (2012). A global review of success story on implementation of fuel economy standard for passenger cars: Lessons for other countries. Energy Education Science and Technology Part A: Energy Science and Research, 29(2), 947-972.

Ministry of Natural Resources and Environment. (2010). Second national communication to the UNFCCC. Malaysia. Retrieved April 9, 2014, from http://www.nre.gov.my/ Malay/Alam-Sekitar/Documents/Penerbitan/SECOND\%20N ATIONAL \%20COMMUNICATION\%20TO\%20THE\%20 UNFCCC $\% 20 \% 28 \mathrm{NC} 2 \% 29$.pdf

Moomaw, W. R., \& Unruh, G. C. (1997). Are environmental Kuznets curves misleading us? The case of $\mathrm{CO} 2$ emissions. Environment and Development, 2, 451-463. 
Muller, S. (2013). Urbanization, infrastructure and economic growth in Southeast Asia. Institute for Sustainable Communities. Retrieved July 5, 2014, from http://www. iscvt.org/news/urbanization-infrastructure-and-economic-gro wth-in-asia/

Munasinghe, M. (1999). Growth-oriented economic policies and their environmental impacts. In C. J. M. van den Bergh (Ed.), Handbook of environmental economics (pp. 678708). Cheltenham: Edward Elgar.

Mundaca, T. L., Mansoz, M., Neij, L., \& Timilsina, G. R. (2013b). Transaction costs analysis of low-carbon technologies. Climate Policy, 13(4). doi:10.1080/14693062.2013.781452

Mundaca, T. L., Markandya, A., \& Nørgaard, J. (2013a). Walking away from a low-carbon economy? Recent and historical trends using a regional decomposition analysis. Energy Policy, 61, 1471-1480. doi:10.1016/j.enpol.2013.04.083

NAPIC. (2014). Property stock reports 2003-2013. National Property Information Centre. Retrieved April 16, 2014, from http://napic.jpph.gov.my/portal/portal/eps/Online+Services/ Publication/PublicationPortletWindow?uri=/Publication_EN/ ComPSR EN.htm\&action=2

OANDA. (2014). Historical exchange rates. Retrieved April 16, 2014, from http://www.oanda.com/currency/historical-rates/

Phdungsilp, A. (2009). Comparative study of energy and carbon emissions. Fifth urban research symposium 2009. Retrieved July 5, 2014, from http://siteresources.worldbank.org/ INTURBANDEVELOPMENT/Resources/336387-1256566 800920/6505269-1268260567624/Phdungsilp.pdf

Road Transport Department Malaysia. (2014). Statistics. Retrieved July 25, 2014, from http://www.jpj.gov.my/

Saidur, R. (2009). Energy consumption, energy savings, and emission analysis in Malaysian office buildings. Energy Policy, 37 (10), 4104-4113.

Scrieciu, S., Rezai, A., \& Mechler, R. (2013). On the economic foundations of green growth discourses: The case of climate change mitigation and macroeconomic dynamics in economic modelling. WREs Energy and Environment, 2(3), 251-268. doi:10.1002/wene. 57

Shafik, N., \& Bandyopadhyay, S. (1992). Economic growth and environmental quality: Time series and cross-country evidence (Background paper for the World Development Report 1992). Washington, DC: The World Bank.

Silitonga, A. S., Atabani, A. E., \& Mahlia, T. M. I. (2012). Review on fuel economy standard and label for vehicle in selected ASEAN countries. Renewable and Sustainable Energy Reviews, 16, 1683-1695.

Smith, K. R., \& Ezzati, M. (2005). How environmental health risks change with development: The epidemiologic and environmental risk transitions revisited. Annual Review of Environment and Resources, 30, 291-333.

Spaargaen, G., \& Mol, A. P. J. (2013). Carbon flows, carbon markets, and low-carbon lifestyles: Reflecting on the role of markets in climate governance. Environmental Politics [Coming of Age? Environmental Politics at 21], 22(1), 174-193. doi:10.1080/09644016.2013.755840

SPAD. (2013). Land public transport master plan. Land Public Transport Commission. Retrieved July 24, 2014, from http://eps.mbpj.gov.my/SlideTod/MBPJ_GKLKV_Nov2013 SPAD.pdf
Steer, A. (2013). Resource depletion, climate change and economic growth. Global Citizen Foundation (Working Paper 5). Retrieved December 4, 2014, from http://www.gcf.ch/wpcontent/uploads/2013/06/GCF_Steer-working-paper-5_6.20. 13.pdf

UNDESA. (2013). World population prospects: The 2012 revision. United Nations Department of Economic and Social Affairs. Retrieved May 15, 2014, from http://esa.un. org/wpp/

UNDESA. (2014). Emissions per capita (tCO2-e). United Nations Department of Economic and Social Affairs. Retrieved April 9, 2014, from http://unstats.un.org/unsd/default.htm

UNDP, \& Malaysian Public Works Department. (2009). Building sectors energy efficiency project. United Nations Development Programme, Malaysian Public Works Department. Retrieved April 16, 2014, from http://www. thegef.org/gef/sites/thegef.org/files/repository/11-30-09\%20 ID3598\%20-\%20Council\%20letter.pdf

UNFCCC. (1992). United Nations Framework Convention on Climate Change. Retrieved July 21, 2014, from http:// unfccc.int/resource/docs/convkp/conveng.pdf

UTM, IRDA, Kyoto University, Okayama University, \& National Institute for Environmental Studies. (2013). Low Carbon Society Blueprint for Iskandar Malaysia 2025 (2nd ed.). Johor Bahru: UTM-Low Carbon Asia Research Centre. Retrieved October 14, 2014, from http://www.utm.my/ partners/satreps-lcs/publications/

WHO. (2014). Urban population growth. Geneva: Author. Retrieved May 15, 2014, from http://www.who.int/gho/urban health/ situation_trends/urban_population_growth_text/en/

WMO. (2014). Johor Bahru, Malaysia. Author. Retrieved December 4, 2014, from http://worldweather.wmo.int/en/ city.html? cityId $=78$

World Bank. (1992). World development report. New York, NY: Oxford University Press.

World Bank. (2014a). Upper middle income. Washington, DC: Author. Retrieved July 21, 2014, from http://data. worldbank.org/income-level/UMC

World Bank. (2014b). Energy use ( $\mathrm{kg}$ of oil equivalent per capita). Washington, DC. Retrieved April 9, 2014, from http://data. worldbank.org/indicator/EG.USE.PCAP.KG.OE

World Bank. (2014c). Urban population (\% of total). Washington, DC. Retrieved April 9, 2014, from http://data.worldbank.org/ indicator/SP.URB.TOTL.IN.ZS

World Bank. (2014d). CO2 emissions (metric tons per capita). Washington, DC. Retrieved April 9, 2014, from http://data. worldbank.org/indicator/EN.ATM.CO2E.PC

WRAP. (2010). Waste collection vehicle fuel efficiency trial. Author. Retrieved April 30, 2014, from http://www.wrap. org.uk/sites/files/wrap/WRAP\%20FH\%20and\%20Premier\% 20 Trial $\% 20$ Draft $\% 20$ Report $\% 20$ Final $\% 20$ for $\% 20$ approval $\%$ $200607 \quad 10 \% 20$ HG.pdf

Zanin, L., \& Marra, G. (2012). Assessing the functional relationship between $\mathrm{CO}_{2}$ emissions and economic development using an additive mixed model approach. Economic Modelling, 29, 1328-1337.

Zusman, E., Srinivasa, A., \& Dhakal, S. (2012). Low carbon transport in Asia: Strategies for optimizing co-benefits. London: Earthscan. 